\title{
Proposal for a Special Interest Group in Intensive Care Psychiatry
}

In June 1987 Councll approved the establishment of Special Interest Groups. Procedure for establishing a Special Interest Group:

(1) Any member wishing to establish a Special Interest Group shall write to the Registrar with relevant details.

(2) The Registrar shall forward the application to Council.

(3) If Council approves the principle of establishing such a Special Interest Group then it will direct the Registrar to place a notice in the Psychiatric Bulletin, or its equivalent, asking members of the College to write in support of such a Group and expressing willingness to participate in its activities.

(4) If more than $\mathbf{5 0}$ members reply to this notice, then Council shall formally approve the establishment of the Special Interest Group.

(5) The administrattve support will be similar to that enjoyed by College Divisions. It should be noted therefore, that the College will maintain the list of meetings but will not provide staff to attend meetings, organise conferences, etc.

In accordance with this procedure, Councll has approved the establishment of a Special Interest Group in Intenstve Care Psychiatry, to address issues relating to the provision of care in lowsecure therapeutic environments.

Members are invited to write in support of this Group and express willingness to partic1pate in its activities. Members should write to Ms Gill Gibbins at the College. If $\mathbf{5 0}$ members reply to this notice, then Council shall formally approve the establishment of this Special Interest Group.

PROFESSOR C. THOMPSON

Registrar 